Kohl: a Journal for Body and Gender Research

Vol. 5, No. 2 (Summer 2019)

\title{
The Non-Work Of The Unimportant: The shadow economy of Nubian women in displacement villages
}

\author{
Menna Agha \\ University of Antwerp
}

\begin{abstract}
:
In my search for spatial resistance in Nubian resettlement villages, I found a trend of spatial hacks located inside and around the household, and purposed to facilitate a shadow economy dominated by women and their small businesses. Despite the recognized importance of informal economies in Africa (Kinyanjui 2014), Nubian women and their society do not qualify their profitable labor as work, partly because of their domestic location and partly because of their roots in an indigenous culture that recognizes the emotional - an undervalued aspect in the formal economy. In this paper, I first present empirical evidence of the significant role these women, and occasionally men, play in the economic health of Nubians after going through the hardships of displacement, by sustaining households as well as preserving Nubian indigenous culture. Second, I highlight the role of these economic activities in expanding the use of dwelling units designed by the state and reforming the built environment. Third, I challenge the ontologies of "work" that have been forced on Nubians as part of their displacement, and discounted their indigenous ontologies of labour. I do so by examining the meaning of "work" as a drive for social and cultural capital. The materiality of displacement and dispossession in the case of Nubians women has occurred semantically: the claim of modernization came accompanied with cultural violence and the discounting of women's labour in the gendered configuration of meaning. This article argues for a feminist ontoepistemology of work - one that recognizes emotion and its position as a capital that is generated and circulated via resources of care, trust, and sense of community.
\end{abstract}




\section{1- Introduction}

Small traders, street merchants, trivial services, and other underemployed groups in urban space (ILO 1972) are what constitutes shadow economy. Often considered the economy of the poor, the informal sector includes the urban poor, such as people living in slums or squatter settlements of developing countries (Moser 1978). In this paper, I look at shadow economy as a form of gendered resistance against the hegemonic systems in post-displacement Nubian villages in Egypt, and examine their impact in countering economic, spatial, and gendered dispossession.

I look at spaces of Nubian women in displacement and their shadow economy with an emic lens; I try to explicate this material, social, and emotional economy that is now discounted in value by both its members and state agents. My main task here is to bridge the gap between the coded and the seen. These phenomena are often concealed from outsiders in state-built settlements that Nubians call tahgeer, or place of displacement, in a rejection of the state's appellation of "New Nubia."

As a Nubian immigrant in Cairo, I lived a dual life: on the one hand, I tried to play the role of an educated urban middle class woman, with my Cairene accent and higher education. On the other hand, my rural Nubian identity blurred the boundaries between village and city. My family has always stressed on the fact that we are different, and the streets of Cairo reflected this difference onto me with its racist tendencies (Smith 2006). Like most Nubian families in big cities, we claimed spatial belonging to our home villages - the original villages, and spent every given holiday in our resettlement village.

Consequently, I found the village to be as effective as the city. The milk I bought from a shop in Cairo bears the same value to me as the one sold by Wafaa, the Nubian woman my grandmother sent me to in order to fetch milk. When I learned that neither does Wafaa consider herself a working woman nor is she considered a worker, I immediately recognized the disparity between both settings, which I problematize as a form of gendered injustice.

My dual positionality allows me to decode the unseen signs of Nubian women's daily experiences, and to learn about a system that operates in the periphery of a dominant system. This duality is reflected in the methodology of this paper: part self-ethnography, part interviews, I build on my lived experience in Qustul as well as stories and narratives that have been orally transmitted to me, whether informally or in structured interviews. As a Nubian scholar, I dedicate academic resources to connect Nubian women and their struggles to their peers elsewhere. More importantly, I attempt to locate their spatial performance and economy in terms of resistance as well as resilience in the face of geographical and semantical displacement.

\section{2- Nubian Displacements}

Nubians have been displaced since the start of the 20th century. The construction of the Aswan Low Dam and its subsequent heightening submerged vast areas of Nubian land, especially agrarian land. Dam constructions affected Nubia's economies since 1902: it led to a widespread and institutional migration of male workforce. As for women, they were left behind to fill the labour gap that was caused by the 
migration of men. They were also tasked with maintaining Nubian traditions, culture, and identity (Armgard Goo-Grauer 2018). The Nubian displacement by dams was sealed with the construction of the Aswan High Dam, then considered a hallmark of the modern Egyptian state.

By 1963, the postcolonial state had displaced 50,000 Nubian families (Fernea 1963). Reports by the World Bank and the world commission on dams underlined the negative economic effects of dams on most people affected by DIDR (development-induced displacement and development) (World Commission on Dams 2000). The DIDR schemes' promise of modernization and prosperity for the displaced is debunked by the material reality of women bearing a greater load in most cases, including in the case of Nubians in Egypt, as shown by these same reports and as heavily documented in the literature on displacement (Choi 2013; Weist 1995; Cook 1996; DeWet 2000).

In the case of Nubians, the economic effects of DIDR on women started prior to their exclusion from early participatory processes. The loss of Nubian women's material positions was already felt in the preparative stages of their displacement. Animals and livestock died in quarantine; if they survived they were to die from the lack of food in the settlement. Each household owned a certain number of cows, goats, sheep, and chickens - economic resources that Alan Horton (1964) considers a matter of wealth for Nubian women, especially in areas that lost their arable land due to the heightening of the low dam. By losing livestock, women lost a major economic bargaining chip.

\section{Problematizing the formal economy}

The resettlement of Nubians in Egypt did not fulfill its promised economic prosperity. Nubian women in particular suffered significant economic losses. In the first years followed their displacement, Nubian women had to sell their golden artefacts to meet living expenses and complete the unfinished houses the Egyptian government had housed them in. They also lost a great deal of land tenure to bureaucracy: since women were not allowed to obtain identification documents in that area before the 1960s, all their land ownership was identified informally, which was not recognized by the state in the process of compensations.

The government's pervasive intervention in the main economic activities of Nubians in new settlements handed the keys of the agricultural economy to men: early development funds were directed towards an agriculture regime exclusively designed for men, in the form of training courses and financing for machinery (Mahgoub 1999), under the unspoken claim that wealth will trickle down to women and the household. Moreover, the conversion from a traditional palm date economy to a sugarcane-based one dispossessed this economy of its meaning and connotation of revered womanhood. Materially, Nubian women had been active partners in the palm tree economy, an additional source of wealth they were stripped of. Today, the state's exclusive administration and monopoly over sugarcane crops, its control over pesticides and fertilizing supply, and the limited possibilities for land expansion in the displacement villages contribute to lower income for Nubian men who are now the supposed main breadwinners of the Nubian household. 
The economic hardships of Nubian women are not alien to the postcolonial African experience; it has exposed, once again, the failure of the postcolonial nation-state and its modernist aspirations in offering economic growth to the victims of its developmental endeavors. Under this regime, the informal economy grew; informal, casual, and poorly paid work abounded; land tenure, labour insecurities, and poor livelihood were the outcomes for the majority of people in Africa (Tsikata 2009); and the shift to a centralized market economy undermined the traditional production systems (Britwum 2006). Similarly, Nubians had to navigate a new life that was not designed for them and that rendered them marginal and dispossessed.

Nevertheless, Nubian women carved spaces for themselves by first joining vocational training then holding government jobs, as the postcolonial socialist state in Egypt was adamant about utilizing women in the labour forces. Interviews conducted in the 1970 s portray a sense of progress and equality among Nubian female employees (Fernea 1987). What theoretically sounds like a Marxist feminist utopia proved to be unsustainable in later years following displacement: no longer a sufficient source of income, only a small percentage of Nubian women could maintain such limited jobs.

More recently, Nubian women's participation in the formal labour force has been significantly lagging behind men's. Their lack of visible participation in the formal public sphere and measurable economic arenas reinforces the stereotypical perception of Muslim women as non-agents in, excluded from, or lacking interest in economic affairs. These notions are partially valid, as Nubian women's participation in public spheres is discouraged by religious ideology. However, Nubian women are heavily involved in the informal economy, shadowing Egypt's economic structures that caused a high unemployment rate in addition to economic exclusion. In other words, they managed to invent ways through which they solved some of their economic problems informally.

Women's preponderance in the survivalist shadow economy is attributed to a history of colonial urbanization (Akyeampong and Agyei-Mensah 2006). Later adopted by ambitious postcolonial states, accelerated urbanization encouraged predominantly male labour to move to industrial and administrative centers. This and the discriminatory character of formal education meant that women participated in the economy on its margins while performing the critical functions to reproduce the labour force: trading in goods and services was an attractive option and this area of the informal economy became dominated by women in many countries and contexts (lbid.).

\section{The other economy}

"We buy this bread from our neighbor; it is a project she does from home ... She doesn't work, but her husband is a clerk at the agricultural center." That was the answer one of my female cousins gave me when I enquired about the source of the "sun-leavened" bread in Qustul, one of the villages relocated by Egypt's High Dam of the 1960s where I spent most of my summers. Conversations with Nubians in the settlement of Qustul about women and work often dismiss informal activities as a "simple" selling of merchandise "to bring in a little more income" to their household. Despite their common occurrences, neither Nubian women nor their social surroundings consider these activities as work. Field work in Qustul 
(2016) shows this not to be the case: some of these businesses generate a steady income and are indispensable to the economy of the household.

Nubian men, who are no longer interested in a state-controlled agriculture economy, opt to migrate for wage labour to urban centers in Egypt, or more commonly to the Gulf. The state-operated economy has led to the continuation of the migration that was already institutionalized in Nubian society before resettlement. Syeda, a Nubian women in her 70s, tells me: "They lied to us; they said that the new villages would have everything and that our men will come back," referring to the state's promise that resettlement will end the diaspora of Nubian men. However, because of their continuous migration for the sake of wage labour, the resettlement villages were once again predominantly populated by women.

As an economically disadvantaged area, the displaced villages witnessed a gradual increase in unemployment rates since their move to the new settlement. Therefore, women have turned parts of their houses into a business. In some cases, women even run complex enterprises of invisible activities. The shadow economy is often associated with criminal activity and "black" markets (Schneider and Enste 2013). In the case of marginalised communities in Egypt, it is an everyday operation that breaks away from the hegemony of the state. Neither do women seek recognition for this work and its impact on the larger economy of the village, nor do they consider themselves workers. However, they dominate the invisible sector of the Nubian economy and control its management.

Anthropologist Anne M. Jennings (1998) studied Nubian women in West Aswan, a Nubian village displaced by the Aswan Low Dam. She suggests that patriarchal attitudes that designate men as breadwinners may largely be responsible for propagating economic stereotypes about women's labour. Jennings offers an analysis of shadow economies of Nubian women, describing them as strategies of survival for women at the margins (45-59).

The distance - literal and metaphorical - between the Nubian settlements and the central governing bodies in Egypt has helped the Nubian shadow economy remain invisible and operate without being subjected to central governance, policing, and taxation. However, changes that take place on larger economic scales affect small businesses significantly, transforming the shadow economy into a semicyclical one. Nubian women have grown interest in Egyptian economic news, as their shadow economy is linked to and inflected by the larger economy regulated by the state. The Nubian women business owners I talked to in 2016 discussed at length the government's decision to float the Egyptian pound, which caused inflation and significant increases in prices without an increase in income among displaced Nubians, and with raw material and basic products tripling in price.

Endemic inflation that constantly raises the cost of living adds to the problem of not enough paid jobs. Informal labor under these conditions - a global economic condition of our times - becomes the primary means for daily survival. The informal economy, globally, is where women work for money. Nubian women's informal jobs in the shadow economy are located in their interpersonal connections and emotional labor, as well as their embeddedness in the fabric of settlements. Therefore, this informal shadow economy is primarily one of care. I use the term "informal" in its technical capacity alone, to refer to economies outside centralized systems of control, or the state. In no way do I see this system as a referral to an unstructured entity: despite being labelled informal, the shadow economy has a form. 
The women I interviewed in this study allude to an implicit agreement among home-based businesses to decrease the prices of merchandise that depend on basic materials affected by inflation. The increase in prices, especially of food, has caused a surge in, or rather a return to, homegrown food products. Raising poultry, for instance, requires daily care and conveniently priced nutrition, such as leftovers of household meals - tasks that integrate well with the daily life of Nubian women. Larger co-operatives have started to expand on similar initiatives, especially for meat production. These village-wide initiatives see both men and women involved in securing proteins all year round.

Women's shadow economy contributes to creating wealth and mitigating larger economic problems. Despite their large impact on the household income, their labour is not considered work and their footprint in the political public sphere of the village remains limited. Yet, I identify three main added values of this economy when it comes to resources and locality: first, it redefines the use of state-built dwelling units; second, it capitalizes on and validates an emotional economy; and third, it preserves a "Nubian culture" that has no place in the macroeconomy.

\subsection{Home Work}

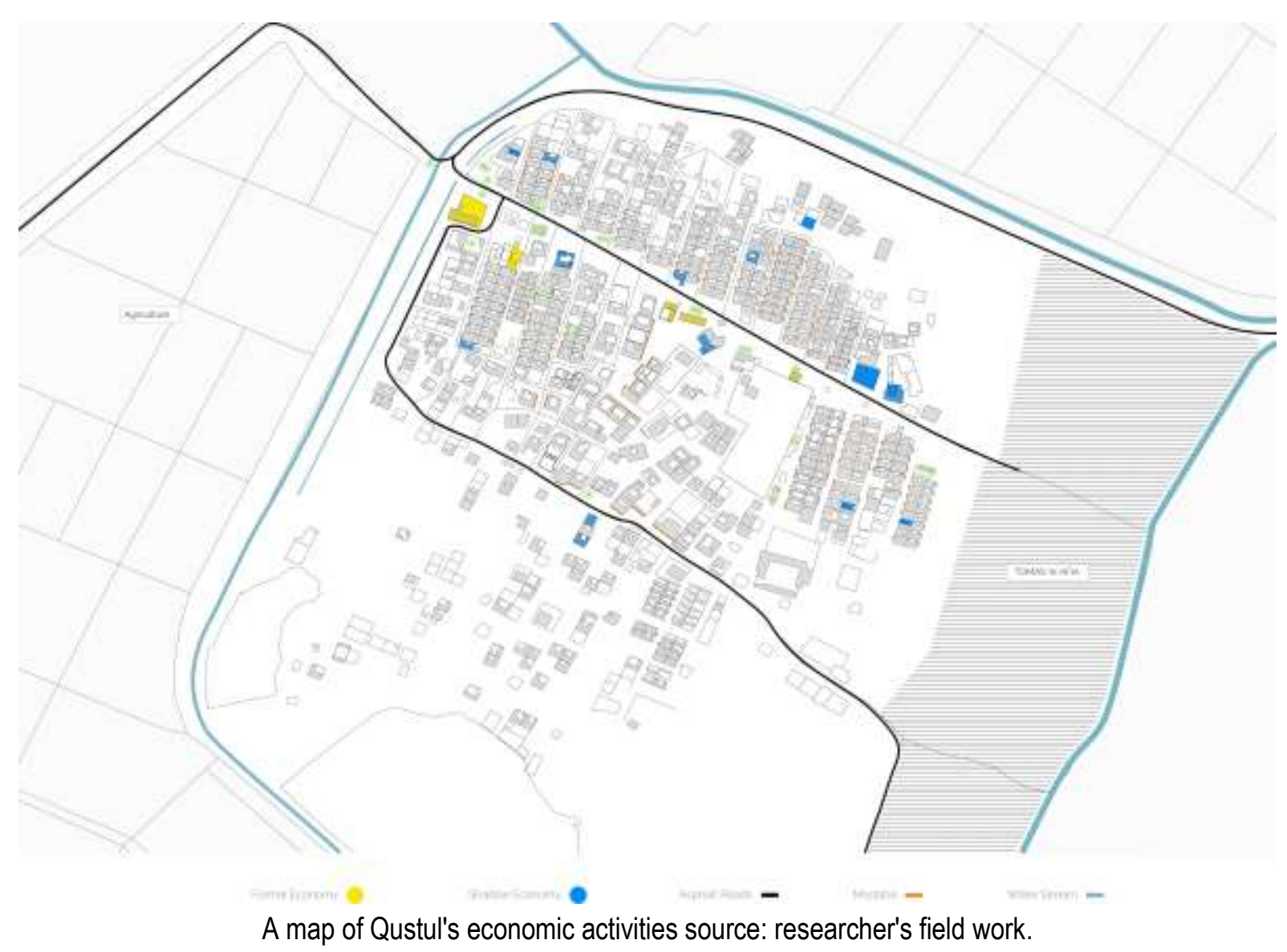

A map of Qustul's informal activities would show that about 15 percent of households operates permanent economic activities from within, altering the land use of the settlement's configuration. Baking, catering, 
tutoring, sewing or selling clothes, and doing hair, makeup, and beauty treatments are all activities that take place inside, around, and within the threshold of the domestic sphere. This shadow economy altered the architectural form of the home. from changes in furniture such as turning a space into a commercial kitchen, to adding rooms to accommodate certain activities, to using simple insulation and fire protection techniques with consideration of wind direction and weather changes.

Within this economy, women have modified and subverted the state-offered housing units. In addition to interior alterations, some business owners annexed a room or kiosk to their houses, merging a quasipublic quality to a supposedly private sphere. These added structures have revived the use and manufacturing of traditional thatching materials that Nubians found cheaper and technically more feasible than modern materials. As some businesses are seasonal or temporary, traditional temporary structures of Nubian architecture heritage alimented the need for a retractable architecture, which ultimately contributed to the preservation of these construction techniques. People in Qustul often open a market inside their houses instead of walking to the center of the village to buy urgent products, such as tea or soft drinks. ${ }^{1}$ For instance, in a relatively remote neighborhood of the village, a family turned one of their house rooms overlooking the street into their own shop window. Because of their location, their business flourished. They then expanded by adding a kiosk next to and a thatched shade over that window. Thatching traditionally served temporary structures for farmers, a shrinking segment of the workforce. With young men increasingly turning towards urban jobs, the demand for thatching is very low, making of it a craft about to be extinct. It is those new needs within the shadow economy that have conferred a renewed purpose to that craft.

The woman who makes the bread my cousin buys runs a small bakery in the courtyard of her state-built dwelling. In addition to turning her guest room into a garment-making workshop, she performs simple food processing operations with her children while watching television. Her monthly earnings are, to her least assessment, double her husband's modest government salary. She doesn't recognize her enterprise as work, as it is something she undertakes at home. To her, work is what is done in the "formal" and "public" space.

The geography of the house, conventionally treated as a private space, is vulnerable to gender biases: the house becomes the landmark of biological essentialism. It is thus regarded as a space that cannot transcend the social (Held 1990). But in the case of Nubian geographies, particularly Qustul's, the domestic sphere is a space that facilitates other economies. In doing so, the public sphere is brought into the house, which can no longer be theorized as a private space deemed "apolitical." Despite considering the concept of work as contained in formally public spheres alone, Nubian women summon the political, economic, and social abilities of the Nubian traditional house, redirecting them into their minimal dwelling units to extend their powers.

\subsection{Emotional Banking}

\footnotetext{
${ }_{1}^{1}$ Tea and soft drinks are the quickest purchases in a Nubian house, especially in the event of multiple guests. Women would typically send their children to the closest seller to fetch these products, which are usually left on credit and paid for later.
} 
Within the shadow economy of Qustul, effective micro-financing networks (jam'iyya) take place: the initiator of a financing cycle asks their trusted circles, mostly women, to join a financial pool by paying a regular contribution, whether weekly, monthly, bi-monthly, or other (Habbob 2018). Similarly, people look for pools that suit their economic needs and abilities. Once a pool agrees on a timeframe, the circle assigns a person responsible for managing the finances (banking) - often a trusted woman. The banker/manager collects and allocates the funds in a timely manner (e.g. each month), and conducts a random draw to decide on the succession of payment to participants. Usually, a need surpasses the random draw; participants can agree among each other - under the banker's coordination - that those in pressing need are paid first. People who are financially well-off often join these co-ops out of social honour and duty, and often get paid last.

It is the poor people's bank "where money is not idle for long but changes hands rapidly, satisfying both consumption and production needs" (Bouman 1983). Moreover, this banking system does not trade in money alone; it is also an exchange of care and honour. Habbob (2018) tells the story of Fatom Jaara, a woman in her eighties who has been managing a jam'iyya since 1970, in the displaced Nubian village of Thomas Wa Afia, now located in Esna, 55 kilometers south of Luxor. In the 1970s, her participants used to pay 0.25 EGP per month. Today, the monthly share is 1,000 EGP per person. Fato Jaara's jam'iyya is one of many old banks that can be found in all the displacement villages and that helped the funding of buildings, weddings, travels, school supplies, and more, despite their inhabitants' lack of relations with formalized or big banks.

Home businesses in Qustul also initiate financial cycles of their own, especially those selling seasonal and relatively expensive merchandise, like carpets and blankets. Such strategies of innovative financial solutions allowed to fund the structures of small enterprises and helped people with financial difficulties to sell their businesses on credit or in instalments. These financial systems were possible because Nubian women capitalized on the emotional assets of trust, care, and familiarity in order to redefine the roles of buying and selling, depending predominantly on the domestic sphere to host most of their activities.

\subsection{Economies of preservation}

With the loss of the old land, raw materials like specific types of palm trees were submerged. As a result, Nubians lost many crafts and trades that relied on these materials to make certain artefacts and food preserving containers. At the same time, the new space of displacement forced a change in rhythm and performance of the everyday. However, Nubians tried to preserve their culture by building economic projects around traditional practices. In the informal economy, women's income-earning activities are often extensions of their traditional roles (Tsikata 2009), which means their efforts to preserve these crafts is a means to preserve their traditional gender roles and powers.

When looking at the indigenous activities of Nubians, we only find them traded within the invisible sphere. Traditional foods, for example, are foreign to the Egyptian manufacturer, and the Nubian society is too small of a market for them to introduce a new product. Therefore, the task of preserving Nubian traditional food and food industries lies on the shoulders of Nubian women. As part of bringing their task to 
completion, they also developed the manufacturing tools and the preparation process, and found a space of usage, value, and development for handcrafts that were part of Nubian heritage.

The existence of Nubian products allowed for Nubian culture to still be performed in the settlement and in the diaspora. In one case, two women partnered to re-function their inherited house into a small sha'riyya (Nubian Noodles) factory, but kept the house structure intact as a sign of respect to the original owner. They effectively applied what modern conservation studies label "adaptive reuse." As their business grew, their sha'riyya was sent to and sold in major cities; Nubians in diaspora sit in a circle around a communal plate just as their ancestors did before the displacement, to recreate a scene that is quintessentially Nubian. During such activities and because of these industries, a Nubian cultural institution finds the space to flourish, particularly in developing economic networks of trust and care.

\section{Discussions on work, capitals, and morality}

The shadow economy is gendered along spatial as well as social lines. Although studies prove that homebased labour is common among men and women, it is evident that more women work from home than men (Kazimbaya Senkwe 2004). Thus, women in the informal economy often experience the environmental, social, and occupational challenges of their living space more intensely; they are the first line of defense against environmental changes that affect their material surrounding, and they have to contend with the systemic depoliticization of "home." They also have to perform multiple roles that include both monetary and care responsibilities, such as childcare.

Despite the fact that Qustul's shadow economy has a quantifiable added value, and despite women's role in mitigating larger economic challenges, labour invested in this economy is under-appreciated and discounted. The economy of Nubian women generates a steady income that is indispensable to most households. However, when not considered "work," what this labour yields is often dissolved in household economics without adding to these women's material wealth, which calls for a categorical ontological problematization of "work." The economic definition of work has excluded activities of women, since Adam Smith's seminal work "The Wealth of Nations" in 1776, in which he identifies an economy as a product of self-interests and work as the effort we put in to fulfil such self-interest, excluding women's activities and the economy of care. Feminist writer Katrine Marçal then asks in the title of her book "Who Cooked Adam Smith's Dinner?," referring to the fact that he famously lived with his mother most of his life, who inevitably was his caregiver.

Whether care work stays in the confines of the nuclear family or extends to the community as is the case in Nubian settlements, it remains under a value contract of a patriarchal system. This kind of emotional and domestic labour is dispossessed of the term "work" with what it carries in meanings of honour over the contribution to the larger society and the ability to create added value. I believe this dispossession is designed to maintain a gender role and a value system in which women's performance is confined into reproductive work (of humans and of values) that assists a larger, more important cycle of "production." It is an attempt to keep their womanhood in "its place" so that it will not interrupt the larger system. 
The problem I identify is limited to discarding care from being work, but it is also the failure to appreciate the extent of it abilities. Care labour is often discussed in terms of human care - child care, elderly care, or disability care. But this case shows that care labour seeps into and adds value to other aspects of life, such as the built environment. In other words, care is to make space, metaphorically and materially. Care labour in the indigenous social contract of Nubians has an added value reward; in the palm tree economy, for example, a single palm tree is often equally owned by three people: the land owner, the shoot provider, and the date caretaker, who often was a women. Care work in the palm tree economy was integral and a source of wealth and ownership, in contrast to care being a depreciated wage labour in the "modernized" world.

A further indictment of modernism, the legitimate offspring of enlightenment (Dhawan 2014), is its birthing to the idea of "professionalization." Professionalism has denied workers a labeled recognition for their labour, unless they are accepted and accredited within the system. For example, with the institutionalization of architecture, credit for a building became exclusively reserved to the institutionally trained. The 20th century became "The Age of Disabling Professions" according to Ivan Illich (1977), because the professionalization of so much life/work contributed to the disabling of nonprofessionals and their imaginings. I blame such modernist dogma for the disregard to the profitable labour of Nubian women: by owning the exclusive rights to defining and legitimizing a profession, the modern institutions of postcolonial Egypt have prevented the Nubian cultural imaginary from naming the phenomenon of the shadow economy.

Shadow economy is, as previously mentioned, a network of semi-cyclic flow of capital, or rather capitals. Capital here is used in a Marxist sense, meaning it is growing out of the process of its circulation. The mention of the plural capital(s) relies on Bourdieu's approach, in which there are different types of capital that account for an individual's insertion in a social system. For Bourdieu (1989), the capital's social effect is tied to social determinants, deriving from an individual's position within the social field, the amount of social, cultural, and economic resources that she or he possesses, and the personal trajectory experienced. He proposes a seminal taxonomy of capital: social capital refers to being in a social network of supporters, retainers, and family members; economic capital refers to ownership of material wealth, shares, and stocks; and cultural capital refers to educational qualifications, charisma, and distinctions within the fields of art and science. These capitals are dependent on institutional moral contracts that evaluate their added value to the network.

This taxonomy discards the emotional, which later required a feminist expansion of Bourdieu's threefold characterisation of capital (Nowotny 1981; Reay 2000; Reay 2004; Silva 2007). I believe Bourdieu's overlooking of the emotional in his theorisation of capitals to be an indictment of an epistemic and social regime, in which the emotional is confined to bounds of "given" labour, e.g. caregiver, as most emotional work does not offer a return to its giver. This contradicts the concept of capitals, in which one form of capital can be transformed into another (Bourdieu 2011). The lack of recognition of emotional capital makes it unable to be transformable into social capital, like the honour that accompanies the recognition of women's activities as work.

The central economic systems brought by colonialism, as Akua Britwum (2006) argues, have caused the discounting of women's work by distorting the traditional relations among household, community, and 
market boundaries, which redefined gender identities against the interest of women. For Nubians after displacement, the new state-controlled economic system succeeded in gradually diminishing the value of the emotional, which was the cornerstone of the Nubian ethos and a defining factor of Nubian gender roles. However, these gender contracts have changed with the change of power institutions. As Butler argues (1988), gender roles are a product of political interest of those in power. Therefore, the shadow economy that resists the central system and its marginalization of Nubians and their wellbeing functions to recall and depend upon Nubian indigenous gender contracts, in which community service and care based work is appreciated. In other words, this shadow network carves a space where escaping the gender roles of the formal political institution becomes possible.

How do we reconcile the woman conjuring the indigenous gender contract in her activities with the individual who reduces her contribution to the unimportant? Judith Butler's (1988) theory of gender performance stipulates that gender is a result of political interest. In their displacement, Nubian women have to contend with conflicting interests: those that benefit her people within a central system (e.g., performing this system's gender roles and be considered a financial dependent), and those that seem beneficial to their economic need (e.g., starting a project or managing a micro-financing co-op). As a result, a Nubian woman alternates from one gendered performance to another, depending on circumstance, embodying their very contradictions.

To address the larger moral system, one could heed philosopher Virginia Held's (2005) call for the "ethics of care." The moral framework that recognises the value of care work acknowledges that economies are not generated by the power of self-interest alone; rather, the power of care can produce economies and wealth like those of Nubian displaced women. Instead of considering law and government or the economy as the central determinants of society, an ethics of care could see bringing up children and fostering trust between society members as the most important concerns (Held 2005). Although Held's proposition means reproductive work, it is applicable to the Nubian shadow economy, as it offers an alternative paradigm in which priorities are different. Therefore, the flow of resources can be movable in a different direction.

Held imagines a realm in which women's work is recognized by economists; she believes such consideration will help "undermine the assumed greater importance of 'production' over 'reproduction,' 'public' over 'private,' and male over female" $(2005,163)$. Therefore, recognizing the value of women's labour in the invisible economy as "work" is crucial for a gender transformative agenda; labelling it as such would grant women the cultural and social capital, and consequently the power to be part of formal and informal decision making.

\section{Conclusion}

The Nubian shadow economy is an economy of care; it can be defined as "small-scale businesses that operate under the African indigenous market concept and that consist of a gathering of traders with strong social relations and associations based on friendship, kinship and ethnicity" (Kinyanjui's 2014, 1). These moral principles are able to add value to the displaced community, as Nubian women - and men - do in 
their economy. The mainstream understanding of economic informality is shortsighted precisely because of its large misrepresentation and underestimating of the economies of care in urban growth.

The shadow economy can affect change on the built environment and its agency. More importantly, it helps to recategorize space away from its state-issued meaning, as illustrated in the example of the dwelling unit becoming a non-private space. This economy can also preserve a social contract that is able to mobilize emotional resources towards economic resilience, especially in mitigating the problems of the macro-economy. Finally, it serves to maintain what is Nubian: by making my traditional food, they are preserving the Nubian taste palate; by making my dresses, they are maintaining Nubian aesthetic.

The shadow economy is work, and this work is important. It is a space of resistance and production of value simultaneously, in addition to signposting the qualitative and quantitative contributions of Nubian women in saving their society from the hardships of capitalism. Therefore, I subscribe to a feminist ontoepistemology of work, in which work is also emotional, tough, and passed on in different ways within a multitude of cultural institutions. 


\section{References}

Armgard Goo-Grauer. "House Decoration in Egyptian Nubia Prior to 1964." Dotawo: A Journal of Nubian Studies 5 (2018): 13-24.

Bouman, F.J.A. "Indigenous Savings and Credit Societies in the Developing World." In Rural Financial Marketing in Developing Countries, Their Use and Abuse. Washington, DC: World Bank, 1983.

Bourdieu, Pierre. "Social Space and Symbolic Power." Sociological Theory 7, no. 1 (1989): 14-25.

_. "The Forms of Capital. (1986)." Cultural Theory: An Anthology 1 (2011): 81-93.

Britwum, Akua. "13 Female Union Leadership, Power, Dynamism and Organised Labour in Ghana." Gendering and Diversifying Trade Union Leadership, 2012, 265.

Britwum, Akua O., Nana K. Tekyi Ghartey, and Patrick K. Agbesinyale. Organizing Labour in the Informal Sector: The Conditions of Rural Agriculture in Ghana (A TUC Ghana-University of Cape Coast, APADEP Case Study). Ghana Universities Press, 2006.

Butler, Judith. "Performative Acts and Gender Constitution: An Essay in Phenomenology and Feminist Theory." Theatre Journal 40, no. 4 (1988): 519-531.

Choi, N. "Displaced: The Human Cost of Development and Resettlement. By Olivia Bennett and Christopher McDowell." Journal of Refugee Studies 26, no. 4 (December 1, 2013): 604-5.

Cook, Cynthia. Involuntary Resettlement in Africa. World Bank Technical Papers. The World Bank, 1994. CRASSH Cambridge. Sara Ahmed Lecture - Uses of Use - Diversity, Utility and the University, 2018.

De Wet, Chris. "The Experience with Dams and Resettlement in Africa." World Commission on Dams Working Paper, Prepared as an Input to the World Commission on Dams, Cape Town, Thematic Review I 3 (2000): 6-7.

Dhawan, Nikita. Decolonizing Enlightenment: Transnational Justice, Human Rights and Democracy in a Postcolonial World 24 (2014). Verlag Barbara Budrich.

Fernea, Elizabeth Warnock, Robert Alan Fernea, and Aleya Rouchdy. Nubian Ethnographies. Waveland Press Prospect Heights, IL, 1991.

Fernea, Robert A. "The Ethnological Survey of Egyptian Nubia." Current Anthropology 4, no. 1 (February 1, 1963): 122-23.

Fernea, Robert A., and John G. Kennedy. "Initial Adaptations to Resettlement: A New Life for Egyptian Nubians." Current Anthropology 7, no. 3 (1966): 349-354.

Fernea, Robert A., and Aleya Rouchdy. "Contemporary Egyptian Nubians." In Nubian Culture: Past and Present, Main Papers Presented at the Sixth International Conference for Nubian Studies in Uppsala, Stockholm, Akmqvist and Wiksell International, 1987.

Habbob, Maher. "Community Sharing: Three Nubian Women, Three Types of Informal Co-Ops." Dotawo: A Journal of Nubian Studies 5, no. 1 (December 29, 2018).

Held, Virginia. "Feminist Transformations of Moral Theory." Philosophy and Phenomenological Research 50 (1990).

- The Ethics of Care: Personal, Political, and Global. Oxford University Press, 2005.

Hopkins, Nicholas S., and Sohair R. Mehanna. Nubian Encounters: The Story of the Nubian Ethnological Survey 19611964. Oxford University Press, 2011.

Horton, Alan W. "The Egyptian Nubians." The American Universities Field Staff Reports Service, Northwest Series XI, no. 2 (1964): 283-302.

Illich, Ivan. "Disabling Professions." Eweb:17615. 1977. 
James, Selma. "Women's Unwaged Work-the Heart of the Informal Sector." Women: A Cultural Review 2, no. 3 (December 1991): 267-71.

Jennings, Anne M. Nubian Women and the Shadow Economy. University Press of Florida, 1998.

- The Nubians of West Aswan: Village Women in the Midst of Change. Lynne Rienner Publishers, 1995.

Kinyanjui, Mary Njeri. Women and the Informal Economy in Urban Africa: From the Margins to the Centre. Zed Books, 2014.

Mahgoub, Yasser Osman Moharam. "The Nubian Experience: A Study of the Social and Cultural Meanings of Architecture." University of Michigan, 1990.

Marçal, Katrine. Who Cooked Adam Smith's Dinner? A Story of Women and Economics. Pegasus Books, 2017.

Moser, Caroline O. N. "Informal Sector or Petty Commodity Production: Dualism or Dependence in Urban Development?" World Development 6, no. 9 (1978): 1041-64. https://doi.org/10.1016/0305750X(78)90062-1.

Nicholas, Claire Margaret. "Exploring Availability for Contemporary Nubian People to Access Their Cultural History and Removed Heritage. A Case Study Based on Egyptian Nubians, Discussing the Access They Have to Their Heritage Which Is Curated Outside of Egypt, Learning about Their History, and Preservation of Memories about a Past Life." April 25, 2017.

Schneider, Friedrich, and Dominik H. Enste. The Shadow Economy: An International Survey. Cambridge University Press, 2013.

Smith, Adam. The Wealth of Nations [1776]. 1937.

Smith, Elizabeth. "Place, Class and Race in the Barabra Cafe." Cairo Cosmopolitan: Politics, Culture, and Urban Space in the New Globalized Middle East. American University in Cairo Press, 2006, 399-413.

Tsikata, Dzodzi. "Gender, Land and Labour Relations and Livelihoods in Sub-Saharan Africa in the Era of Economic Liberalisation: Towards a Research Agenda." Feminist Africa 12, no. 2 (2009): $11-$ 30.

Tsikata, Dzodzi, and Dede-Esi Amanor-Wilks. "Land and Labour in Gendered Livelihood Trajectories." Feminist Africa 12 (2009): 1-9.

Weist, Katherine M. "Development Refugees: Africans, Indians and the Big Dams." J. Refugee Stud. 8 (1995): 163.

World Commission on Dams. Dams and Development: A New Framework for Decision-Making: The Report of the World Commission on Dams. Earthscan, 2000. 